\title{
Improved cultivation and metagenomics as new tools for bioprospecting in cold environments
}

\author{
Jan Kjølhede Vester • Mikkel Andreas Glaring • \\ Peter Stougaard
}

Received: 11 August 2014 / Accepted: 28 October 2014 / Published online: 16 November 2014

(C) The Author(s) 2014. This article is published with open access at Springerlink.com

\begin{abstract}
Only a small minority of microorganisms from an environmental sample can be cultured in the laboratory leaving the enormous bioprospecting potential of the uncultured diversity unexplored. This resource can be accessed by improved cultivation methods in which the natural environment is brought into the laboratory or through metagenomic approaches where culture-independent DNA sequence information can be combined with functional screening. The coupling of these two approaches circumvents the need for pure, cultured isolates and can be used to generate targeted information on communities enriched for specific activities or properties. Bioprospecting in extreme environments is often associated with additional challenges such as low biomass, slow cell growth, complex sample matrices, restricted access, and problematic in situ analyses. In addition, the choice of vector system and expression host may be limited as few hosts are available for expression of genes with extremophilic properties. This review summarizes the methods developed for improved cultivation as well as the metagenomic approaches for bioprospecting with focus on the challenges faced by bioprospecting in cold environments.
\end{abstract}

Communicated by S. Albers.

J. K. Vester $\cdot$ M. A. Glaring $\cdot$ P. Stougaard $(\varangle)$

Department of Plant and Environmental Sciences, University

of Copenhagen, Thorvaldsensvej 40, 1871 Frederiksberg C,

Denmark

e-mail: psg@plen.ku.dk

J. K. Vester

e-mail: jkv@plen.ku.dk
Keywords Bioprospecting - Cultivation · Metagenome · Cold-active $\cdot$ Functional metagenomics $\cdot$ Multiple displacement amplification

$\begin{array}{ll}\text { Abbreviations } \\ \text { BAC } & \text { Bacterial artificial chromosome } \\ \text { gDNA } & \text { Genomic DNA } \\ \text { iChip } & \text { Isolation chip } \\ \text { MDA } & \text { Multiple displacement amplification } \\ \text { PIGEX } & \text { Product-induced gene expression screening } \\ \text { Rpf } & \text { Resuscitation-promoting factors } \\ \text { SIGEX } & \text { Substrate-induced gene expression screening } \\ \text { SIP } & \text { Stable isotope probing } \\ \text { FACS } & \text { Fluorescence-activated cell sorting }\end{array}$

\section{Introduction}

Bioprospecting is the discovery and commercialization of new products such as enzymes and bioactive compounds based on biological resources. Generally speaking, bioprospecting of microorganisms can be conducted by culture-dependent or metagenomic approaches. The culturedependent approaches are based on cultivation of natural isolates that can be screened for activities of interest, e.g., enzyme activities, antimicrobial activities or antibiotic resistances. However, only a small minority of microorganisms from an environmental sample can be cultured by standard techniques-often on conventional cultivation media in Petri dishes-and typically, less than $1 \%$ of the total cell counts can be cultured in the laboratory (Amann et al. 1995). This discrepancy between the total number of bacteria from an environmental sample and the viable plate count has been termed "The Great Plate Count Anomaly" (Staley and Konopka 1985). The uncultivability of bacteria 
can be due to many factors, including lack of specific nutrients, oxygen level, temperature, $\mathrm{pH}$ and osmotic conditions as well as missing growth factors, possibly produced by other organisms in the community (Vartoukian et al. 2010). Culturing will always favor the organisms that are best at adapting to the conditions applied in the laboratory, and these organisms are not necessarily the most dominant or ecologically important organisms in the environment. Insights into the uncultured fraction have been fueled by sequencing of the 16S rRNA genes of bacteria from environmental samples, and this in turn has resulted in the identification of numerous new bacterial phyla, of which very few are represented by cultivated strains (Achtman and Wagner 2008; Stewart 2012).

Several methods that allow exploitation of the vast majority of microorganisms that are difficult to cultivate in the laboratory have been described. The methods can basically be divided into (1) improved cultivation techniques or (2) metagenomic methods. The improved cultivation techniques can be used to establish pure cultures or complex communities available for culture-dependent screenings or metagenomic approaches. The metagenomic methods are either based on sequencing of metagenomes and bioinformatic analysis or functional expression of metagenomic libraries to identify genes or gene clusters of interest.

Bioprospecting in extreme environments with nonstandard conditions, such as low temperature, is met with additional challenges. Conventional cultivation may be difficult because of insufficient knowledge on media requirements or very prolonged incubation time, enrichment in situ may be problematic if the environment is located in remote areas, metagenomic analyses may be hampered by low amounts of environmental DNA, and heterologous expression of enzymes and other bioactive molecules may be challenging since most host organisms are not developed for extreme conditions. This review will present the methods developed for improved cultivation as well as the metagenomic approaches for bioprospecting with focus on the challenges faced by bioprospecting in cold environments. The methods that have been developed to deal with these problems will be summarized and possible routes to future improvements will be highlighted.

\section{Cultivation-based bioprospecting}

A number of techniques have been developed for improved cultivation of natural microorganisms in the laboratory or in situ in the environment. Although only a few of these methods have been used specifically to bring cold-adapted microorganisms into culture, they all have the potential to increase the output of cultivation-based bioprospecting projects in cold environments. It is important, however, to keep in mind that cold-adapted microorganisms are faced with several challenges imposed by the low temperature. These include increased water viscosity, decreased diffusion rates, and not least reduced biochemical reaction rates (Feller 2013). For most biological systems, the activity of a mesophilic enzyme will be $16-80$ times lower at $0{ }^{\circ} \mathrm{C}$ than at $37^{\circ} \mathrm{C}$ (Georlette et al. 2004). In general, cold-active enzymes maintain a high biochemical reaction rate at low temperature by having a more flexible structure, resulting in a lower substrate affinity and increased heat lability (Feller and Gerday 2003; Feller 2013). Therefore, when designing experiments, care should be taken not to expose enzymes or organisms to elevated temperatures, as this might lead to irreversible inactivation of enzymes.

If communities or pure cultures can be established under laboratory settings, they will in many cases be suitable for bioprospecting efforts. Most techniques have been developed for traditional laboratory conditions, e.g., $20^{\circ} \mathrm{C}$, 1 atm., pH 7, etc., and are often not directly applicable to organisms originating from extreme environments. However, since most laboratories are equipped with facilities that allow incubation at low temperatures, screening of cultivated cold-adapted organisms can be carried out simply using existing assays at low temperature. A classic example is plate-based screening using chromogenic substrates that develop detectable colors upon activity (Fathallh et al. 2012), and by combining a mixture of different insoluble chromogenic substrates, multiple activities can be detected by various color combinations in single plate experiments (Ten et al. 2004, 2005). Subsequent identification and cloning of genes of interest have been aided by the emergence of genomics and access to affordable whole genome sequencing of bacterial isolates.

The cultivation-dependent method of bioprospecting can involve several steps, ranging from traditional culturing to the various versions of optimized culturing conditions discussed below (Fig. 1). The subsequent isolation, screening and purification of microorganisms are typically done by plating on Petri dishes to obtain pure cultures for further analysis. Although improved cultivation methods may increase the proportion of cultivable microorganisms, many of these organisms will not grow as pure cultures in the laboratory. In addition, the specific gene or gene cluster responsible for the trait of interest often has to be identified to facilitate more efficient expression and characterization than possible with the natural isolate. Organisms solely capable of growing as microcolonies or in mixed communities can be analyzed by metagenomic approaches, which may also be applied directly to environmental samples. A useful coupling of culture-dependent and metagenomic methods is to use genomic DNA (gDNA) or cDNA from enrichment cultures or pure natural isolates for metagenomic methods (Hobel et al. 2004). 


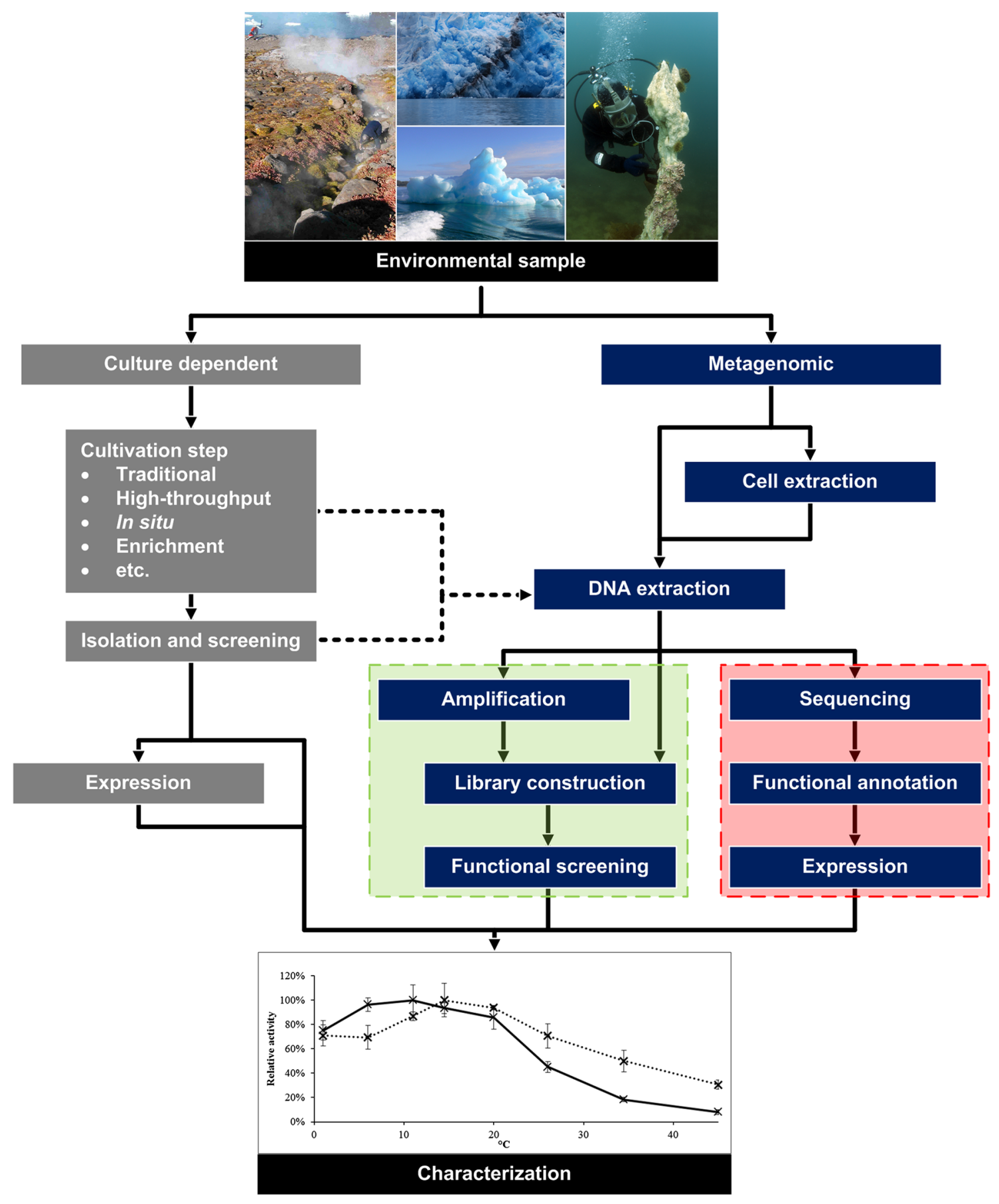

Fig. 1 Simplified and general overview of culture-dependent and metagenomic methods for bioprospecting. In principle any environmental sample can be used. Culture-dependent methods (gray boxes) include a culturing step ranging from traditional culturing to various combinations of improved culturing techniques, leading to isolation and screening of natural isolates. Metagenomic methods (blue boxes) rely on DNA extraction, which can be either direct or indirect.

Methods for improving cultivation

To bring more microorganisms into culture, it is reasonable to try to mimic the natural environment in the culturing
Extracted DNA can be used for either sequence-based (red) or functional (green) screening approaches, where the latter might require amplification. Identified activities from natural isolates or recombinantly expressed proteins are then characterized. Links between culture-dependent and metagenomic methods include using DNA from enrichment cultures or natural isolates (dotted lines). See text for details. Inspired by Akondi and Lakshmi (2013)

conditions, e.g., by simulating temperature, $\mathrm{pH}$, oxygen level or light, and using water or materials taken from the environment. An alternative taking this one step further is to bring the natural environment into the laboratory and 

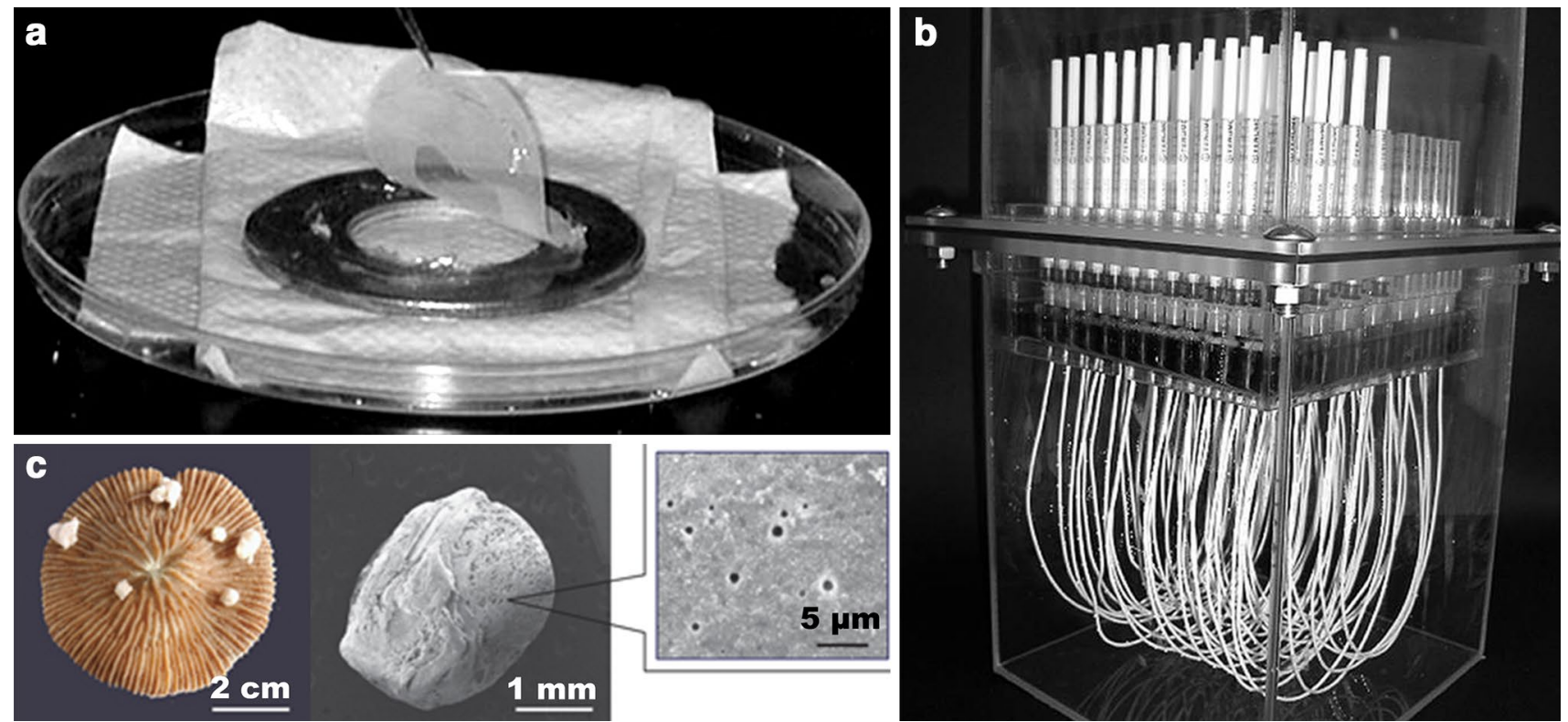

Fig. 2 Cultivation techniques. Diffusion chamber (a), hollow-fiber membrane chambers (b), and encapsulated gel microdroplets (c). Modified from Kaeberlein et al. (2002, (OThe American Association

use this for cultivation of microorganisms by keeping them separated from the environment in situ. Different methods have been developed using this approach, the three most prominent being; diffusion chambers, gel microdroplets, and hollow-fiber membrane chambers (Fig. 2). All of the techniques discussed below could potentially be applied to cold environments without further adjustments, although the various in situ incubation methods could prove difficult to apply for some extreme environments. Remote locations or hostile environments could restrict access as well as require improved performance of materials. In addition, limited knowledge on specific environments could make attempts at optimizing media composition and growth conditions difficult.

\section{Diffusion chamber and isolation chip (iChip)}

In the diffusion chamber developed by Kaeberlein et al. (2002) (Fig. 2a), microorganisms are separated from their environment, embedded in agar and placed in a chamber closed by two permeable membranes. These membranes allow for diffusion of chemical components, and by placing the chamber in an aquarium simulating the natural environment, these components can pass through the membranes and stimulate growth of the separated cells in the chamber. The communities formed in the chambers can then be analyzed directly and purified by diluting into new chambers or by transferring to Petri dishes. Using fresh water sediments to inoculate diffusion chambers and placing them on for the Advancement of Science), Aoi et al. (2009, (CAmerican Society for Microbiology) and Ben-Dov et al. (2009, (John Wiley and Sons), respectively

the sediments for 4 weeks, Bollmann et al. (2007) were able to cultivate bacteria from rarely cultivated groups, and they found that continuous cultivation in diffusion chambers enabled growth of new bacteria in laboratory settings. A highthroughput version of the diffusion chamber, the isolation chip (iChip) developed by Nichols et al. (2010), consists of hundreds of miniature diffusion chambers, each of which can be inoculated with single cells to establish monospecific cultures. The iChip was tested on seawater and soil samples, and both total cell numbers as well as cultured diversity were increased compared to traditional culturing in Petri dishes.

\section{Hollow-fiber membrane chambers}

The hollow-fiber membrane chambers developed by Aoi et al. (2009) take a similar approach by utilizing fibers that allow for exchange of metabolites with the environment. These fibers can be inoculated with microorganisms and placed in natural or engineered environments (Fig. 2b). The system was tested using samples from tidal sediment, activated sludge, and a laboratory bioreactor and led to an increase in diversity as well as in the number of novel cultivable species compared to culturing in Petri dishes (Aoi et al. 2009).

\section{Gel microdroplets and I-tip}

Zengler et al. (2002) developed a high-throughput method for growing encapsulated microorganisms in gel microdroplets kept in a continuous fed-batch system with a 
low nutrient flux to simulate environmental conditions. The pores in the gel microdroplets allow for exchange of metabolites between organisms captured in separate droplets. Millions of microdroplets can be present in each growth column, and each growth column can be placed in specific media and growth conditions. Gel microdroplets with microcolonies are then identified by flow cytometry. The system was tested using seawater samples, and the highest diversity was obtained when filtered seawater was used as growth medium compared to seawater with nutrients added, suggesting that most of the diversity is outcompeted by relatively few fast growing organisms in a rich environment (Zengler et al. 2002). A technique combining the advantageous in situ incubation of diffusion chambers and hollow-fiber membrane chambers with the small size of the gel microdroplets was later developed by encapsulating microorganisms in agar and then further encasing them in a polysulfonic polymeric membrane, which permits exchange of chemical components and allows more flexible in situ incubation by being small (Fig. 2c). By inoculating with microorganisms from coral mucus and placing the encased agar on corals for incubation, approximately $50 \%$ of the cultured organisms represented novel ribotypes (Ben-Dov et al. 2009). Unfortunately, no attempts were made to cultivate the microorganisms outside the encased agar. A similar method, the I-tip, was recently developed based on standard laboratory equipment (e.g., micropipette tips). It was used to cultivate bacteria associated with a sponge and was superior to a standard agar-based cultivation with respect to cultured diversity (Jung et al. 2014).

\section{Dilution to extinction}

In the dilution to extinction technique, natural samples are diluted to very low cell concentrations and cultured to establish clonal populations. Connon and Giovannoni (2002) developed a high-throughput version of this method, which allows for cell enumeration of small volumes with low cell densities, making it possible to run the incubations in microtiter plates. This technique was used to culture members of the SAR11 clade which, despite its ubiquity, had previously evaded cultivation (Rappe et al. 2002).

\section{Resuscitation-promoting factors (Rpf)}

Resuscitation-promoting factors ( $\mathrm{Rpf}$ ) are involved in resuscitation of dormant organisms and thereby in increasing their cultivability. Rpf have been intensively studied in Mycobacterium tuberculosis (Mukamolova et al. 1998; Kana et al. 2008) and this knowledge was used to cultivate the otherwise uncultivable strain Psychrobacter sp. strain MSC33 on standard media supplemented with a short Rpf peptide (Nichols et al. 2008).
Gelling agent

Agar is by far the most commonly used gelling agent for microbiology. However, other gelling agents have been shown to be superior to agar in supporting growth of diverse bacteria. Using gellan gum, a water-soluble polysaccharide produced by Pseudomonas elodea, instead of agar, Tamaki et al. (2009) demonstrated that gellan gum not only supported much faster growth of bacteria from a freshwater lake sediment compared to agar, but also supported growth of more novel isolates than agar.

Incubation time

There are several examples of increased cultivability with increased incubation time. Rarely isolated phylogenetic groups of soil bacteria have been cultivated by prolonged incubation (up to 3 months) (Davis et al. 2005; Steven et al. 2007) and a general increase in the diversity of haloarchaeal groups was observed with increasing incubation time (up to 12 weeks) (Burns et al. 2004). In another study, the cultured fraction of sea ice bacteria increased from 0.005 to $0.2 \%$ if the incubation time was prolonged from 5 weeks to 3 months (Lanoil et al. 2009). Extended incubation time (more than 8 months) was found to significantly increase the diversity of cultured bacteria from a cold and alkaline environment, as well as the fraction of unknown genera and species (Vester et al. 2013). Also, many previously uncultured bacteria were discovered if multiple growth media were used (Joseph et al. 2003) and an increase in cultured diversity was observed if solid media were used rather than liquid (Vester et al. 2013).

\section{Sub-zero incubation}

Cryophiles are extremely cold-adapted organisms capable of living in brine veins surrounding soil particles in permafrost soils or in ice brine veins at sub-zero temperatures. Such organisms can be cultured in media with high salt concentration supplemented with glycerol as shown for Planococcus halocryophilus, which was able to grow at temperatures as low as $-15^{\circ} \mathrm{C}$ (Mykytczuk et al. 2013).

\section{Metagenome-based bioprospecting}

Since the culture-dependent methods only catch a very limited fraction of the total diversity of a given sample, metagenomic methods for bioprospecting can be highly valuable. Although these methods do not require cultivation, they may be restrained by the amount and quality of DNA obtainable from the environment or community of interest. The metagenomic approach can either be sequence 
based, involving high-throughput sequencing and bioinformatic analysis, or function based, aimed at functional expression of metagenomic libraries to identify genes or gene clusters of interest (Fig. 1).

\section{Sequence-based metagenomics}

The sequence-based approach includes screening for genes by hybridization with labeled DNA probes or by PCR, both of which are based on sequences of known genes (Aakvik et al. 2011; Simon and Daniel 2011; Lee and Lee 2013). Since the price for direct high-throughput sequencing of metagenomic DNA has reached a level affordable for many laboratories (de Pascale et al. 2012; Hunter et al. 2012), this is now the standard technology for gene discovery (Ekkers et al. 2012). As outlined in Fig. 1, the sequence-based approach consists of three main steps: (1) the sequencing itself (2) bioinformatic analyses including functional annotation of genes, and finally (3) the heterologous expression of identified genes to document activity. For each of these steps, different opportunities exist and choices have to be made.

The various high-throughput sequencing platforms each have their advantages and disadvantages and the generated sequences subsequently go through a series of steps including quality control, filtering, assembly, and functional annotation of assembled sequences. Details of the sequencing platforms and sequence handling procedures have recently been reviewed by Loman et al. (2012) and Kim et al. (2013), respectively. It is important to note that functional annotation is generally based on sequence homology (Hunter et al. 2012; Kim et al. 2013) and since annotations are based on already known and characterized sequences, completely novel sequences are likely not to be annotated correctly or simply not annotated at all. To illustrate this, of six million proteins identified in a survey of fully sequenced bacterial genomes, the function of approximately $40 \%$ was classified as unknown (Blaby-Haas and de Crecy-Lagard 2011).

The outcome of the sequencing and bioinformatics pipeline is typically a long list of genes of interest, which has to be investigated further to choose the best candidates for expression. Only $2.8 \%$ of more than 20 million proteins in the UniProt database have had their existence confirmed at either the protein or transcript level (Temperton and Giovannoni 2012), indicating that a significant part of the annotated genes might not be expressed in the laboratory or at a too low level in Nature to be detected. Nevertheless, a prioritized list of expression targets can be made from analyses of properties of similar proteins, signal peptides, degree of novelty, etc., and the sequence information can be used for codon optimization and choice of expression organism.
Function-based metagenomics

Functional metagenomics is the study of a metagenome by expression in a foreign host. This approach involves critical decisions regarding DNA fragment size, vectors and expression hosts (Ekkers et al. 2012). As for the sequencebased approach, the starting point is DNA (or cDNA). This has to be of good quality in terms of purity and fragment length. If the concentration of the purified DNA is too low for cloning, as is often the case for extreme environments, the DNA can be amplified by multiple displacement amplification (MDA) (Taupp et al. 2011).

\section{DNA isolation}

Both gDNA and cDNA can be used for metagenomics and the DNA can be obtained from different sources including environmental samples (directly or indirectly isolated), enrichment cultures or pure isolates. Due to the difficulties in isolating mRNA from environmental samples, studies using cDNA are rare (Simon and Daniel 2011). For both enrichment cultures and pure isolates, isolation of mRNA is more feasible than for complex environmental samples. Also, if eukaryotic genes are of interest for a functional bioprospecting approach using a prokaryotic host for expression, cDNA is necessary to circumvent problems introduced by introns in gDNA (Aakvik et al. 2011). Direct extraction of DNA from environmental samples involves the in situ lysis of cells within the sample matrix and DNA extraction, whereas indirect sampling involves the isolation of cells from the sample matrix before ex situ lysis. The result from direct extraction is typically higher yield but more fragmented DNA, whereas indirect extraction yields are lower but with larger DNA fragments. Which method to choose depends on the sample matrix as well as the intended uses. Direct extraction can result in co-extraction of inhibitory substances such as humic acids from soil or the matrix may itself adsorb the DNA. Unwanted DNA such as eukaryotic or extracellular DNA can also constitute a significant part of the extracted DNA (Kakirde et al. 2010a; Aakvik et al. 2011; Williamson et al. 2011; Akondi and Lakshmi 2013; Lee and Lee 2013). These problems can be circumvented by indirect extraction. This is time consuming and biased, as it is unlikely that all types of cells separate from the sample matrix or remain intact during separation, with the result that the representativeness of the DNA will be affected (Ekkers et al. 2012). A study comparing direct and indirect DNA extraction from soil communities revealed that although the yield and quality of DNA were significantly different between the two methods, functional diversity was similar, probably due to functional redundancy in the community (Delmont et al. 2011). Bias is also introduced by the choice of lysis and DNA 
extraction method and it is likely that an accurate representation of the community will never be achieved. In general, it is advisable to apply multiple extraction methods, and when working with environments with low biomass, as is the case for many extreme environments, DNA yields are often low (Aakvik et al. 2011; Vester et al. 2014a, b). To obtain sufficient amounts of DNA for further analyses, MDA with the $\varphi 29$ DNA polymerase can be applied (Spits et al. 2006). MDA is, however, heavily biased and will not generate quantitative results (Yilmaz et al. 2010; Vester et al. 2014b) and there is a risk of introducing point mutations (Aakvik et al. 2011).

DNA from more defined sources than environmental samples can also be used for bioprospecting. Several coldactive enzymes have been identified by screening genome libraries from single isolates with desirable properties, including a $\beta$-glucosidase from Paenibacillus xylanilyticus KJ-03 (Park et al. 2013), a $\beta$-D-galactosidase from Paracoccus sp. 32d (Wierzbicka-Wos et al. 2011) and an esterase from Psychrobacter pacificensis (Wu et al. 2013).

Enrichment cultures can be used to select for microorganisms with specific desirable traits. The relative fraction of DNA most likely to contain genes of interest is increased by reducing the overall complexity of the community (Cowan et al. 2005; Taupp et al. 2011; Ekkers et al. 2012). Among other studies, this approach has been used to enrich organisms capable of utilizing chitin as a carbon source at alkaline pH (Kielak et al. 2013) and identifying cellulolytic organisms (Grant et al. 2004). Although most microorganisms cannot be cultivated, more are able to grow in the mixed community of an enrichment culture than as pure isolates and using DNA extracted from these cultures will, therefore, yield different results than those obtained from culture-dependent screenings from the same enrichment culture (Entcheva et al. 2001; Voget et al. 2003). An alternative approach to enrichment is to use stable isotope probing (SIP) where a labeled $\left({ }^{13} \mathrm{C}\right.$ or $\left.{ }^{15} \mathrm{~N}\right)$ substrate is added and utilized by metabolically active organisms that incorporate the heavier atoms into their DNA, which can subsequently be separated by density gradient centrifugation (Kakirde et al. 2010a; Ekkers et al. 2012).

\section{Vectors}

The length of the fragments used for cloning depends on the type of screening library. There are three main types of functional expression libraries: plasmid $(<15 \mathrm{~kb})$, fosmid (25-35 kb)/cosmid (25-40 kb), and bacterial artificial chromosomes (BACs, 100-200 kb) (Ekkers et al. 2012). Plasmids are typically easy to handle and are suitable for single gene products such as most enzymes, and transformation efficiencies are high. Due to the small insert size, they are not useful when whole operons need to be detected
(Taupp et al. 2011) and endogenous promoters might not be included. Using a plasmid with two promoters flanking the multiple cloning site may facilitate gene expression independently of insert orientation and endogenous promoter sequences (Lammle et al. 2007). For larger fragments, cosmids, fosmids, or BACs are used. These larger fragments and vectors are more difficult to handle, but offer the possibility of including entire operons and gene clusters as well as achieving a better sequence coverage with fewer clones. The commercially available CopyControl kit from Epicentre Biotechnologies can be used to generate fosmid libraries with $\sim 40 \mathrm{~kb}$ inserts with a high cloning efficiency and stability in Escherichia coli, and is a frequently used method for expression libraries of metagenomic DNA (Table 1) (Lee and Lee 2013; Cheng et al. 2014). Since the hit rate in functional screening is typically very low $(<2$ out of 10,000 clones screened), high cloning efficiency and high-throughput screening are crucial for successful identification of activities (Akondi and Lakshmi 2013; Lee and Lee 2013). Shuttle vectors carrying multiple origins of replication can be used to move the library between different expression hosts, such as Gram-negative and Gram-positive bacteria. This is particularly useful for libraries made from environments with mixed communities.

\section{Expression hosts}

The choice of expression host will influence the design and result of functional expression on all levels. E. coli is by far the most commonly used host due to the substantial genetic toolbox available (Aakvik et al. 2011), but methods for using other organisms have been developed. Functional expression faces the same challenges associated with heterologous expression: codon usage, improper promoter recognition, missing initiation factors, protein misfolding, missing co-factors, breakdown of product, improper secretion of product, toxicity of product or intermediates, and formation of inclusion bodies (Ekkers et al. 2012). Since the origin of metagenomic DNA is unknown, it is impossible to predict the effect of these potential problems, as they may vary from gene to gene and may depend on the expression host. Gabor et al. (2004) estimated that $40 \%$ of the genes from 32 different bacterial and archaeal genomes contained expression signals that would be recognized in $E$. coli. However, the actual fraction of genes that can be successfully expressed in E. coli is probably significantly lower, as missing co-factors, chaperones, secretion, etc., was not considered. Not surprisingly, heterologous expression in $E$. coli is more efficient for closely related organisms (Warren et al. 2008). E. coli has been engineered to increase the expression of heterologous genes by improving the recognition of ribosomal binding 
Table 1 Cold-active enzymes identified by functional metagenomics

\begin{tabular}{|c|c|c|c|c|c|c|c|}
\hline Enzyme & Host/vector & $\begin{array}{l}\text { Positive/total } \\
\text { clones }\end{array}$ & $\begin{array}{l}\text { Screening } \\
\text { technique }\end{array}$ & $T_{\text {opt }}$ & $\mathrm{pH}_{\mathrm{opt}}$ & Origin of sample & References \\
\hline Lipase & E. coli/fosmid & $70 />7,000$ & Agar based & 35 & N.A. & Baltic sea sediment & $\begin{array}{l}\text { Hardeman and } \\
\text { Sjoling (2007) }\end{array}$ \\
\hline Lipase & E. coli/cosmid & N.A. & Agar based & 30 & 7 & $\begin{array}{l}\text { Oil-contaminated soil } \\
\text { (Northern Germany) }\end{array}$ & Elend et al. (2007) \\
\hline Lipase & E. coli/fosmid & $1 / 8,823$ & Agar based & 25 & 8 & $\begin{array}{l}\text { Deep-sea sediment (Papua } \\
\text { New Guinea) }\end{array}$ & Jeon et al. (2009a) \\
\hline Lipase & E. coli/fosmid & $1 / 6,000$ & Agar based & 30 & 8 & Intertidal sediment (Korea) & Kim et al. (2009) \\
\hline Lipase & E. coli/plasmid & 2/N.A. & Agar based & 20 & $7-9$ & $\begin{array}{l}\text { Soil from different altitude of } \\
\text { Taishan (China) }\end{array}$ & Wei et al. (2009) \\
\hline Lipase & E. coli/fosmid & $1 / 2,400$ & Agar based & 35 & 8 & Mangrove sediment (Brazil) & Couto et al. (2010) \\
\hline Lipase & E. coli/fosmid & $1 / 386,400$ & Agar based & 25 & 8 & Tidal sediment (Korea) & Lee et al. (2012) \\
\hline Lipase & E. coli/fosmid & $6 / 81,100$ & Agar based & $30-35$ & $7.5-8.5$ & Deep-sea sediment & Jeon et al. (2011) \\
\hline Esterase & E. coli/fosmid & 1/N.A. & Agar based & $50-55$ & $10-11$ & $\begin{array}{l}\text { Deep-sea sediment (Papua } \\
\text { New Guiney) }\end{array}$ & Park et al. (2007) \\
\hline Esterase & E. coli/fosmid & $3 / 100,000$ & Agar based & 40 & 9.0 & Antarctic desert soil & Heath et al. (2009) \\
\hline Esterase & E. coli/fosmid & $6 / 60,132$ & Agar based & 30 & 8 & Arctic seashore sediment & Jeon et al. (2009b) \\
\hline Esterase & E. coli/fosmid & 1/N.A. & Agar based & 35 & 7.5 & Arctic intertidal sediment & Fu et al. (2013) \\
\hline Esterase & E. coli/fosmid & $3 / 100,000$ & Agar based & 20 & 11 & Antarctic desert soil & Hu et al. (2012) \\
\hline Esterase & E. coli/fosmid & $1 / 31,872$ & Agar based & 35 & 8.5 & Swamp sediment (Korea) & Seo et al. (2014) \\
\hline Esterase & E. coli/fosmid & $121 / 60,000$ & Agar based & $20-30$ & 9 & Arctic soil & Yu et al. (2011) \\
\hline Esterase & E. coli/phage & $95 / 274,000$ & Agar based & $15-40$ & $8-10$ & Oil-contaminated seawater & $\begin{array}{l}\text { Tchigvintsev et al. } \\
\text { (2014) }\end{array}$ \\
\hline $\begin{array}{l}\text { Phthalate Esters } \\
\text { Hydrolase }\end{array}$ & E. coli/fosmid & N.A./100,000 & Agar based & 10 & 7.5 & $\begin{array}{l}\text { Wastewater treatment plant } \\
\text { (China) }\end{array}$ & Jiao et al. (2013) \\
\hline Amylase & E. coli/cosmid & $1 / 350,000$ & Agar based & 40 & 6.5 & Soil (Himalaya) & Sharma et al. (2010) \\
\hline Amylase & E. coli/BAC & $2 / 2,843$ & Agar based & 15 & $8-9$ & Ikaite columns (Greenland) & Vester et al. (2014a) \\
\hline Cellulase & E. coli/BAC & $11 / 10,000$ & Agar based & $10-50$ & $6-9$ & Antarctic soil & $\begin{array}{l}\text { Berlemont et al. } \\
\text { (2009) }\end{array}$ \\
\hline Cellulase & E. coli/plasmid & $1 / 8,500$ & Agar based & 28 & 4.5 & Cold desert (Himalaya) & Bhat et al. (2013) \\
\hline Cellulase & E. coli/plasmid & $1 / 40,000$ & Agar based & 40 & 7 & $\begin{array}{l}\text { Brown alga associated } \\
\text { microorganism (France) }\end{array}$ & Martin et al. (2014) \\
\hline$\beta$-Galactosidase & E. coli/plasmid & $3 / 1,200$ & Agar based & 38 & 7 & Topsoil of oil field (China) & Wang et al. (2010) \\
\hline$\beta$-Galactosidase & E. coli/BAC & $2 / 2,843$ & Agar based & 37 & $6-7$ & Ikaite columns (Greenland) & Vester et al. (2014b) \\
\hline$\beta$-Galactosidase & E. coli/plasmid & $1 / 1,100$ & Agar based & 40 & 6.5 & Baltic sea water & $\begin{array}{l}\text { Wierzbicka-Wos } \\
\text { et al. (2013) }\end{array}$ \\
\hline Xylanase & E. coli/phagemid & $1 / 5,000,000$ & Agar based & 20 & $6-7$ & $\begin{array}{l}\text { Waste lagoon of dairy farm } \\
\text { (California) }\end{array}$ & Lee et al. (2006) \\
\hline Chitinase & E. coli/fosmid & $1 / 29,000$ & Agar based & 30 & N.A. & $\begin{array}{l}\text { Genomes from Antarctic } \\
\text { soil (1) and Arctic sea (9) } \\
\text { bacteria }\end{array}$ & Kim et al. (2014) \\
\hline DNA polymerase & $\begin{array}{l}\text { I E. coli/plasmid and } \\
\text { fosmid }\end{array}$ & $\begin{array}{l}15 / 23,000 \text { and } \\
1 / 4,000\end{array}$ & Growth assay & N.A. & N.A. & Glacial ice (Germany) & Simon et al. (2009) \\
\hline
\end{tabular}

Adapted and updated from Cavicchioli et al. (2011, @ John Wiley and Sons)

N.A. not applicable or not available

sites, expressing more chaperones, and/or enhancing secretion (Aakvik et al. 2011; Ekkers et al. 2012). An example of such an engineered host strain is the Arctic Express E. coli strain (Agilent Technologies), which has been optimized for low temperature expression by inclusion of chaperones from the psychrophilic bacterium
Oleispira antarctica. This is beneficial since the native $E$. coli chaperones have highly reduced activity at low temperatures. Also, by engineering the EPI300 E. coli strain of the CopyControl kit from Epicentre to express two additional sigma factors from Clostridium and Streptomyces, the hit rate in a functional screening was 
increased by $20-30 \%$ (Liebl et al. 2014). Alternatively, the psychrophilic Gram-negative bacterium Pseudoalteromonas haloplanktis TAC125 has been established as a system for expression and secretion of recombinant proteins (Cusano et al. 2006). To deal with improper secretion, Li et al. (2007) developed a vector system that enables forced cell lysis inducible by UV radiation to avoid the use of costly, time-consuming, and possibly denaturing lysing agents.

If phylogenetic information on the metagenomic DNA is available, or if the proteins of interest are known to be highly abundant in a specific type of bacteria, a related host can be chosen to enhance the chance of successful expression. Alternatively, shuttle vectors that allow for library expression in multiple hosts can be used. The pCC$1 F O S$ vector for fosmid and BAC cloning, which normally only replicates in E. coli, has been modified so it can be transferred to other species by conjugation (Aakvik et al. 2009). Another broad-host-range vector is the pGNS-BAC vector, which features an inducible copy number and has been successfully used in six different $\gamma$-Proteobacteria (Kakirde et al. 2010b). The broad-host-range cosmid vector, pJWC, was used to establish a metagenomic library in six different Proteobacteria, including $\alpha-, \beta$-, and $\gamma$-Proteobacteria, with very little overlap in expression (Craig et al. 2010), confirming the usefulness of multiple hosts.

The shuttle vectors mentioned above have been used in organisms from the same phylum as E. coli and may not be suitable for expression of genes from more distantly related organisms (e.g., Gram-positive bacteria). They can, however, be useful for transferring a library to a host better adapted to the screening conditions. As an example, E. coli is not an optimal host for screening for cold- and alkaline-active enzymes since it does not grow well at low temperatures and not at all at high $\mathrm{pH}$, but a library can be established in E. coli and subsequently transferred to a related host adapted to these conditions to allow for direct assays at low temperature and high pH (Liebl et al. 2014). To deal with a similar problem, Angelov et al. (2009) developed a two-host fosmid system, which permits transfer of a library from $E$. coli to the thermophilic Gram-negative Thermus thermophilus and confirmed that the expression patterns between these two organisms were very different. BAC shuttle vectors that can replicate in both Gram-positive and Gram-negative bacteria have been developed (Hain et al. 2008; Ouyang et al. 2010), including the E. coli-Bacillus subtilis shuttle vector pHT01 from MoBiTech (Biver et al. 2013). Additional commercial shuttle vectors with increased transfer efficiency and flexibility are currently being developed (David Mead, Lucigen, personal communication), which could prove beneficial for increasing the expression rate in metagenomic libraries. Also, the pCC1FOS vector has been modified to allow transfer to Mycobacterium spp. (Ly et al. 2011), and McMahon et al. (2012) developed a shuttle vector for E. coli and Streptomyces lividans and an optimized S. lividans strain for expression. Recently, Cheng et al. (2014) created cosmid vectors for transfer of cloned metagenomic DNA by pentaparental conjugation to Gateway ${ }^{\circledR}$ destination vectors that are able to replicate in hosts such as Bacillus and Saccharomyces.

\section{Screening}

The challenges and limitations of the function-based approach highlight the necessity for a robust and highthroughput screening setup with low detection threshold to capture the few positive clones (Taupp et al. 2011). With function-based metagenomics, it is possible to perform heterologous complementation screenings where the metagenomic inserts complement a given trait in the host organism with the advantage that only positive clones will be able to grow. This approach was used to screen for coldactive DNA polymerase activities using an E. coli strain with a cold-sensitive lethal mutation in DNA polymerase I (Nagano et al. 1999) as a host for a metagenomic library from glacial ice (Simon et al. 2009). Clones with resistance to antibiotics or heavy metals can be selected for by including these substances in the growth medium (Kakirde et al. 2010a).

Another approach for functional screening is substrate-induced gene expression screening (SIGEX) where metagenomic DNA is cloned upstream of a promoterless GFP. This allows for detection of promoters induced by the conditions applied after which, cells can be sorted using fluorescence-activated cell sorting (FACS). This method has been used to identify genes induced by aromatic-hydrocarbon compounds in a groundwater metagenome library in E. coli (Uchiyama et al. 2005). A similar approach is the product-induced gene expression screening (PIGEX) where a reporter strain with a product-sensitive promoter coupled to GFP is co-cultivated with a metagenomic library to facilitate detection of product formation by fluorescence. This has been used to identify amidase activities in E. coli carrying a metagenome library from activated sludge of a wastewater treatment facility (Uchiyama and Miyazaki 2010).

The functional approach has significant benefits, most importantly that it enables the detection of truly novel activities as no prior sequence information is needed. Furthermore, targeted activities are often directly available in a relevant production organism, making the road to optimized expression less troublesome than for the sequence-based approach. Among the main disadvantages are the rather 
labor-intensive setup and the necessity for high-throughput screening to maintain a reasonable hit rate (Aakvik et al. 2011; Simon and Daniel 2011; Taupp et al. 2011).

Cold-active enzymes identified by functional metagenomics

Table 1 lists cold-active enzymes identified by functional metagenomics. It can be seen that bioprospecting for cold-active enzymes has been conducted in many different environments including sediments from both poles, the deep-sea, cold deserts, mountain soils, lakes, and glacial ice. The characteristic low hit rate as well as the preferred use of fosmid libraries and E. coli as host is also obvious. Lipases and esterases dominate the enzyme activities identified, most likely as a result of the easy detection of these activities. The results clearly demonstrate the need for further development of alternative hosts and assays to facilitate easy and efficient screening for additional enzyme activities, since cold-active enzymes have many useful applications.

\section{Applications of cold-active enzymes}

Enzymes from psychrophiles are generally cold active and heat labile, which has three main advantages for biotechnological applications: (1) because of the higher specific activity, less (expensive) enzyme is required; (2) processes can run at the temperature of tap water or ambient temperature reducing the need for heating; and (3) their activity can be (selectively) inactivated by a moderate temperature increase (Feller 2013). Many industrial and biotechnological processes make use of cold-active enzymes or could benefit from their use, as the reduced temperature can be beneficial in multiple ways. Such processes may save energy and production costs, improve hygiene, maintain taste and other organoleptic properties, and reduce the risk of contamination. Cold-active enzymes are used in fine chemical synthesis, environmental biotechnology, biofuels and energy production, and in the food and feed, detergent, pharmaceutical, medical and textile industries (Cavicchioli et al. 2011). Specific examples include the use of coldactive $\beta$-galactosidases to hydrolyze lactose to generate lactose-free milk (Feller 2013), heat-labile $\alpha$-amylases in the baking industry (Coronado et al. 2000) as well as heatlabile phosphatases and nucleases for molecular biology (Feller 2013). In laundry and dish-washing detergents, the use of cold-active enzymes (proteases, cellulases, lipases, and amylases) is especially promising, since they allow for environment-friendly low temperature washing (Horikoshi 1999; van der Maarel et al. 2002; Fujinami and Fujisawa 2010; Mojallali et al. 2013).

\section{Conclusions and perspectives}

Approximately $75 \%$ of the Earth's biosphere is cold $\left(<5{ }^{\circ} \mathrm{C}\right)$ (Huston 2008), and since microbial life is present practically everywhere, this constitutes an enormous reservoir for bioprospecting for cold-adapted activities of interest. Culture-dependent bioprospecting is an important and valuable tool in this regard, but since most microorganisms cannot be easily cultured, if at all, it is limited to covering only a fraction of the total biodiversity. The large uncultivable fraction of microorganisms can potentially be accessed by improved cultivation or through metagenomic approaches and these technologies each have their advantages and disadvantages. Culture-based methods result in organisms that are known to produce potentially novel, active enzymes but the re-discovery rate can be very high (Aakvik et al. 2011; Vester et al. 2014a, b). Sequence-based metagenomics often identifies a large number of genes encoding putative enzyme activities, but there is no guarantee that the genes can be expressed as active enzymes in available heterologous hosts and it also relies on previous sequence knowledge for identification. Function-based metagenomics may result in novel, functionally active enzymes, but the hit rate can be extremely low.

Bioprospecting at low temperature is faced with additional difficulties including low biomass and DNA availability, and the lack of cold-adapted expression hosts for functional metagenomics. Both academia and industry could benefit from a more diverse collection of host strains with various extremophilic properties, including adaptation to low temperature, to increase the likelihood of identifying specific activities of interest. Furthermore, the development of more versatile vectors as well as strain engineering should improve the low hit rate associated with functional metagenomics. The potential of the uncultured microbial diversity is enormous, and with the methods presently available and those currently being developed, this biological resource is becoming increasingly accessible.

Acknowledgments This work was supported by a Grant to JKV from University of Copenhagen.

Conflict of interest The authors declare that they have no conflict of interest.

Open Access This article is distributed under the terms of the Creative Commons Attribution License which permits any use, distribution, and reproduction in any medium, provided the original author(s) and the source are credited.

\section{References}

Aakvik T, Degnes KF, Dahlsrud R, Schmidt F, Dam R, Yu L, Volker U, Ellingsen TE, Valla S (2009) A plasmid RK2-based 
broad-host-range cloning vector useful for transfer of metagenomic libraries to a variety of bacterial species. FEMS Microbiol Lett 296:149-158

Aakvik T, Lale R, Liles M, Valla S (2011) Metagenomic libraries for functional screening. In: de Bruijn FJ (ed) Handbook of molecular microbial ecology, 1st edn. Wiley-Blackwell, Hoboken, pp 171-181

Achtman M, Wagner M (2008) Microbial diversity and the genetic nature of microbial species. Nat Rev Microbiol 6:431-440

Akondi KB, Lakshmi VV (2013) Emerging trends in genomic approaches for microbial bioprospecting. OMICS 17:61-70

Amann RI, Ludwig W, Schleifer KH (1995) Phylogenetic identification and in situ detection of individual microbial cells without cultivation. Microbiol Rev 59:143-169

Angelov A, Mientus M, Liebl S, Liebl W (2009) A two-host fosmid system for functional screening of (meta)genomic libraries from extreme thermophiles. Syst Appl Microbiol 32:177-185

Aoi Y, Kinoshita T, Hata T, Ohta H, Obokata H, Tsuneda S (2009) Hollow-fiber membrane chamber as a device for in situ environmental cultivation. Appl Environ Microbiol 75:3826-3833

Ben-Dov E, Kramarsky-Winter E, Kushmaro A (2009) An in situ method for cultivating microorganisms using a double encapsulation technique. FEMS Microbiol Ecol 68:363-371

Berlemont R, Delsaute M, Pipers D, D'Amico S, Feller G, Galleni M, Power P (2009) Insights into bacterial cellulose biosynthesis by functional metagenomics on Antarctic soil samples. ISME J 3:1070-1081

Bhat A, Riyaz-Ul-Hassan S, Ahmad N, Srivastava N, Johri S (2013) Isolation of cold-active, acidic endocellulase from Ladakh soil by functional metagenomics. Extremophiles 17:229-239

Biver S, Steels S, Portetelle D, Vandenbol M (2013) Bacillus subtilis as a tool for screening soil metagenomic libraries for antimicrobial activities. J Microbiol Biotechnol 23:850-855

Blaby-Haas CE, de Crecy-Lagard V (2011) Mining high-throughput experimental data to link gene and function. Trends Biotechnol 29:174-182

Bollmann A, Lewis K, Epstein SS (2007) Incubation of environmental samples in a diffusion chamber increases the diversity of recovered isolates. Appl Environ Microbiol 73:6386-6390

Burns DG, Camakaris HM, Janssen PH, Dyall-Smith ML (2004) Combined use of cultivation-dependent and cultivation-independent methods indicates that members of most haloarchaeal groups in an Australian crystallizer pond are cultivable. Appl Environ Microbiol 70:5258-5265

Cavicchioli R, Charlton T, Ertan H, Mohd OS, Siddiqui KS, Williams TJ (2011) Biotechnological uses of enzymes from psychrophiles. Microb Biotechnol 4:449-460

Cheng J, Pinnell L, Engel K, Neufeld JD, Charles TC (2014) Versatile broad-host-range cosmids for construction of high quality metagenomic libraries. J Microbiol Methods 99:27-34

Connon SA, Giovannoni SJ (2002) High-throughput methods for culturing microorganisms in very-low-nutrient media yield diverse new marine isolates. Appl Environ Microbiol 68:3878-3885

Coronado M, Vargas C, Hofemeister J, Ventosa A, Nieto JJ (2000) Production and biochemical characterization of an alpha-amylase from the moderate halophile Halomonas meridiana. FEMS Microbiol Lett 183:67-71

Couto GH, Glogauer A, Faoro H, Chubatsu LS, Souza EM, Pedrosa FO (2010) Isolation of a novel lipase from a metagenomic library derived from mangrove sediment from the south Brazilian coast. Genet Mol Res 9:514-523

Cowan D, Meyer Q, Stafford W, Muyanga S, Cameron R, Wittwer P (2005) Metagenomic gene discovery: past, present and future. Trends Biotechnol 23:321-329

Craig JW, Chang FY, Kim JH, Obiajulu SC, Brady SF (2010) Expanding small-molecule functional metagenomics through parallel screening of broad-host-range cosmid environmental DNA libraries in diverse proteobacteria. Appl Environ Microbiol 76:1633-1641

Cusano AM, Parrilli E, Marino G, Tutino ML (2006) A novel genetic system for recombinant protein secretion in the Antarctic Pseudoalteromonas haloplanktis TAC125. Microb Cell Fact 5:40

Davis KE, Joseph SJ, Janssen PH (2005) Effects of growth medium, inoculum size, and incubation time on culturability and isolation of soil bacteria. Appl Environ Microbiol 71:826-834

de Pascale D, De Santi C, Fu J, Landfald B (2012) The microbial diversity of Polar environments is a fertile ground for bioprospecting. Mar Genomics 8:15-22

Delmont TO, Robe P, Clark I, Simonet P, Vogel TM (2011) Metagenomic comparison of direct and indirect soil DNA extraction approaches. J Microbiol Methods 86:397-400

Ekkers DM, Cretoiu MS, Kielak AM, Elsas JD (2012) The great screen anomaly - a new frontier in product discovery through functional metagenomics. Appl Microbiol Biotechnol 93:1005-1020

Elend C, Schmeisser C, Hoebenreich H, Steele HL, Streit WR (2007) Isolation and characterization of a metagenome-derived and cold-active lipase with high stereospecificity for (R)-ibuprofen esters. J Biotechnol 130:370-377

Entcheva P, Liebl W, Johann A, Hartsch T, Streit WR (2001) Direct cloning from enrichment cultures, a reliable strategy for isolation of complete operons and genes from microbial consortia. Appl Environ Microbiol 67:89-99

Fathallh EM, Nagaoka T, Wasaki J, Kouno K (2012) Isolation and characterization of cellulose-decomposing bacteria inhabiting sawdust and coffee residue composts. Microbes Environ 27:226-233

Feller G (2013) Psychrophilic enzymes: from folding to function and biotechnology. Scientifica (Cairo) 2013:512840

Feller G, Gerday C (2003) Psychrophilic enzymes: hot topics in cold adaptation. Nat Rev Microbiol 1:200-208

Fu J, Leiros HK, de Pascale D, Johnson KA, Blencke HM, Landfald B (2013) Functional and structural studies of a novel coldadapted esterase from an Arctic intertidal metagenomic library. Appl Microbiol Biotechnol 97:3965-3978

Fujinami S, Fujisawa M (2010) Industrial applications of alkaliphiles and their enzymes-past, present and future. Environ Technol 31:845-856

Gabor EM, Alkema WB, Janssen DB (2004) Quantifying the accessibility of the metagenome by random expression cloning techniques. Environ Microbiol 6:879-886

Georlette D, Blaise V, Collins T, D’Amico S, Gratia E, Hoyoux A, Marx JC, Sonan G, Feller G, Gerday C (2004) Some like it cold: biocatalysis at low temperatures. FEMS Microbiol Rev 28:25-42

Grant S, Sorokin DY, Grant WD, Jones BE, Heaphy S (2004) A phylogenetic analysis of Wadi el Natrun soda lake cellulase enrichment cultures and identification of cellulase genes from these cultures. Extremophiles 8:421-429

Hain T, Otten S, von Both U, Chatterjee SS, Technow U, Billion A, Ghai R, Mohamed W, Domann E, Chakraborty T (2008) Novel bacterial artificial chromosome vector pUvBBAC for use in studies of the functional genomics of Listeria spp. Appl Environ Microbiol 74:1892-1901

Hardeman F, Sjoling S (2007) Metagenomic approach for the isolation of a novel low-temperature-active lipase from uncultured bacteria of marine sediment. FEMS Microbiol Ecol 59:524-534

Heath C, Hu XP, Cary SC, Cowan D (2009) Identification of a novel alkaliphilic esterase active at low temperatures by screening a metagenomic library from antarctic desert soil. Appl Environ Microbiol 75:4657-4659

Hobel CFV, Marteinsson VT, Hauksdottir S, Fridjonsson O, Skirnisdottir S, Hreggvidsson GO, Kristjansson JK (2004) Use of 
low nutrient enrichments to access novel amylase genes in silent diversity of thermophiles. World J Microbiol Biotechnol 20:801-809

Horikoshi K (1999) Alkaliphiles: some applications of their products for biotechnology. Microbiol Mol Biol Rev 63:735-750

Hu XP, Heath C, Taylor MP, Tuffin M, Cowan D (2012) A novel, extremely alkaliphilic and cold-active esterase from Antarctic desert soil. Extremophiles 16:79-86

Hunter CI, Mitchell A, Jones P, McAnulla C, Pesseat S, Scheremetjew M, Hunter S (2012) Metagenomic analysis: the challenge of the data bonanza. Brief Bioinform 13:743-746

Huston AL (2008) Biotechnological aspects of cold-adapted enzymes. In: Psychrophiles: from biodiversity to biotechnology. Springer, New York

Jeon JH, Kim JT, Kang SG, Lee JH, Kim SJ (2009a) Characterization and its potential application of two esterases derived from the arctic sediment metagenome. Mar Biotechnol (NY) 11:307-316

Jeon JH, Kim JT, Kim YJ, Kim HK, Lee HS, Kang SG, Kim SJ, Lee $\mathrm{JH}(2009 \mathrm{~b})$ Cloning and characterization of a new cold-active lipase from a deep-sea sediment metagenome. Appl Microbiol Biotechnol 81:865-874

Jeon JH, Kim JT, Lee HS, Kim SJ, Kang SG, Choi SH, Lee JH (2011) Novel lipolytic enzymes identified from metagenomic library of deep-sea sediment. Evid Based Complement Alternat Med 2011:271419

Jiao Y, Chen X, Wang X, Liao X, Xiao L, Miao A, Wu J, Yang L (2013) Identification and characterization of a cold-active phthalate esters hydrolase by screening a metagenomic library derived from biofilms of a wastewater treatment plant. PLoS One 8:e75977

Joseph SJ, Hugenholtz P, Sangwan P, Osborne CA, Janssen PH (2003) Laboratory cultivation of widespread and previously uncultured soil bacteria. Appl Environ Microbiol 69:7210-7215

Jung D, Seo EY, Epstein SS, Joung Y, Han J, Parfenova VV, Belykh OI, Gladkikh AS, Ahn TS (2014) Application of a new cultivation technology I-tip, for studying microbial diversity in freshwater sponges of Lake Baikal, Russia. FEMS Microbiol Ecol. doi:10.1111/1574-6941.12399

Kaeberlein T, Lewis K, Epstein SS (2002) Isolating "uncultivable" microorganisms in pure culture in a simulated natural environment. Science 296:1127-1129

Kakirde KS, Parsley LC, Liles MR (2010a) Size does matter: application-driven approaches for soil metagenomics. Soil Biol Biochem 42:1911-1923

Kakirde KS, Wild J, Godiska R, Mead DA, Wiggins AG, Goodman RM, Szybalski W, Liles MR (2010b) Gram negative shuttle BAC vector for heterologous expression of metagenomic libraries. Gene 475:57-62

Kana BD, Gordhan BG, Downing KJ, Sung N, Vostroktunova G, Machowski EE, Tsenova L, Young M, Kaprelyants A, Kaplan G, Mizrahi V (2008) The resuscitation-promoting factors of Mycobacterium tuberculosis are required for virulence and resuscitation from dormancy but are collectively dispensable for growth in vitro. Mol Microbiol 67:672-684

Kielak AM, Cretoiu MS, Semenov AV, Sorensen SJ, van Elsas JD (2013) Bacterial chitinolytic communities respond to chitin and pH alteration in soil. Appl Environ Microbiol 79:263-272

Kim EY, Oh KH, Lee MH, Kang CH, Oh TK, Yoon JH (2009) Novel cold-adapted alkaline lipase from an intertidal flat metagenome and proposal for a new family of bacterial lipases. Appl Environ Microbiol 75:257-260

Kim M, Lee KH, Yoon SW, Kim BS, Chun J, Yi H (2013) Analytical tools and databases for metagenomics in the next-generation sequencing era. Genomics Inform 11:102-113

Kim D, Park HJ, Kim IC, Yim JH (2014) A new approach for discovering cold-active enzymes in a cell mixture of pure-cultured bacteria. Biotechnol Lett 36:567-573
Lammle K, Zipper H, Breuer M, Hauer B, Buta C, Brunner H, Rupp $S$ (2007) Identification of novel enzymes with different hydrolytic activities by metagenome expression cloning. J Biotechnol 127:575-592

Lanoil B, Skidmore M, Priscu JC, Han S, Foo W, Vogel SW, Tulaczyk S, Engelhardt H (2009) Bacteria beneath the West Antarctic ice sheet. Environ Microbiol 11:609-615

Lee MH, Lee SW (2013) Bioprospecting potential of the soil metagenome: novel enzymes and bioactivities. Genomics Inform 11:114-120

Lee CC, Kibblewhite-Accinelli RE, Wagschal K, Robertson GH, Wong DW (2006) Cloning and characterization of a cold-active xylanase enzyme from an environmental DNA library. Extremophiles 10:295-300

Lee $\mathrm{MH}$, Oh KH, Kang CH, Kim JH, Oh TK, Ryu CM, Yoon JH (2012) Novel metagenome-derived, cold-adapted alkaline phospholipase with superior lipase activity as an intermediate between phospholipase and lipase. Appl Environ Microbiol 78:4959-4966

Li S, Xu LH, Hua H, Ren CA, Lin ZL (2007) A set of UV-inducible autolytic vectors for high throughput screening. J Biotechnol 127:647-652

Liebl W, Angelov A, Juergensen J, Chow J, Loeschcke A, Drepper T, Classen T, Pietruzska J, Ehrenreich A, Streit WR, Jaeger KE (2014) Alternative hosts for functional (meta)genome analysis. Appl Microbiol Biotechnol 98:8099-8109

Loman NJ, Constantinidou C, Chan JZ, Halachev M, Sergeant M, Penn CW, Robinson ER, Pallen MJ (2012) High-throughput bacterial genome sequencing: an embarrassment of choice, a world of opportunity. Nat Rev Microbiol 10:599-606

Ly MA, Liew EF, Le NB, Coleman NV (2011) Construction and evaluation of pMycoFos, a fosmid shuttle vector for Mycobacterium spp. with inducible gene expression and copy number control. J Microbiol Methods 86:320-326

Martin M, Biver S, Steels S, Barbeyron T, Jam M, Portetelle D, Michel G, Vandenbol M (2014) Identification and characterization of a halotolerant, cold-active marine endo-beta-1,4-glucanase by using functional metagenomics of seaweed-associated microbiota. Appl Environ Microbiol 80:4958-4967

McMahon MD, Guan C, Handelsman J, Thomas MG (2012) Metagenomic analysis of Streptomyces lividans reveals hostdependent functional expression. Appl Environ Microbiol 78:3622-3629

Mojallali L, Shahbani ZH, Rajaei S, Akbari NK, Haghbeen K (2013) A novel approximately $34-\mathrm{kDa}$ alpha-amylase from psychrotroph Exiguobacterium sp. SH3: production, purification, and characterization. Biotechnol Appl Biochem 61:118-125

Mukamolova GV, Kaprelyants AS, Young DI, Young M, Kell DB (1998) A bacterial cytokine. Proc Natl Acad Sci U S A 95:8916-8921

Mykytczuk NC, Foote SJ, Omelon CR, Southam G, Greer CW, Whyte LG (2013) Bacterial growth at -15 degrees C; molecular insights from the permafrost bacterium Planococcus halocryophilus Or1. ISME J 7:1211-1226

Nagano K, Wachi M, Takada A, Takaku F, Hirasawa T, Nagai K (1999) fcsA29 mutation is an allele of polA gene of Escherichia coli. Biosci Biotechnol Biochem 63:427-429

Nichols D, Lewis K, Orjala J, Mo S, Ortenberg R, O'Connor P, Zhao C, Vouros P, Kaeberlein T, Epstein SS (2008) Short peptide induces an "uncultivable" microorganism to grow in vitro. Appl Environ Microbiol 74:4889-4897

Nichols D, Cahoon N, Trakhtenberg EM, Pham L, Mehta A, Belanger A, Kanigan T, Lewis K, Epstein SS (2010) Use of ichip for high-throughput in situ cultivation of "uncultivable" microbial species. Appl Environ Microbiol 76:2445-2450

Ouyang Y, Dai S, Xie L, Ravi Kumar MS, Sun W, Sun H, Tang D, Li $\mathrm{X}$ (2010) Isolation of high molecular weight DNA from marine 
sponge bacteria for BAC library construction. Mar Biotechnol (NY) 12:318-325

Park HJ, Jeon JH, Kang SG, Lee JH, Lee SA, Kim HK (2007) Functional expression and refolding of new alkaline esterase, EM2L8 from deep-sea sediment metagenome. Protein Expr Purif 52:340-347

Park DJ, Lee YS, Choi YL (2013) Characterization of a cold-active beta-glucosidase from Paenibacillus xylanilyticus KJ-03 capable of hydrolyzing isoflavones daidzin and genistin. Protein $\mathbf{J}$ 32:579-584

Rappe MS, Connon SA, Vergin KL, Giovannoni SJ (2002) Cultivation of the ubiquitous SAR11 marine bacterioplankton clade. Nature 418:630-633

Seo S, Lee YS, Yoon SH, Kim SJ, Cho JY, Hahn BS, Koo BS, Lee CM (2014) Characterization of a novel cold-active esterase isolated from swamp sediment metagenome. World J Microbiol Biotechnol 30:879-886

Sharma S, Khan FG, Qazi GN (2010) Molecular cloning and characterization of amylase from soil metagenomic library derived from Northwestern Himalayas. Appl Microbiol Biotechnol 86:1821-1828

Simon C, Daniel R (2011) Metagenomic analyses: past and future trends. Appl Environ Microbiol 77:1153-1161

Simon C, Herath J, Rockstroh S, Daniel R (2009) Rapid identification of genes encoding DNA polymerases by function-based screening of metagenomic libraries derived from glacial ice. Appl Environ Microbiol 75:2964-2968

Spits C, Le CC, De RM, Van HL, Van SA, Liebaers I, Sermon K (2006) Whole-genome multiple displacement amplification from single cells. Nat Protoc 1:1965-1970

Staley JT, Konopka A (1985) Measurement of in situ activities of nonphotosynthetic microorganisms in aquatic and terrestrial habitats. Annu Rev Microbiol 39:321-346

Steven B, Briggs G, McKay CP, Pollard WH, Greer CW, Whyte LG (2007) Characterization of the microbial diversity in a permafrost sample from the Canadian high Arctic using culturedependent and culture-independent methods. FEMS Microbiol Ecol 59:513-523

Stewart EJ (2012) Growing unculturable bacteria. J Bacteriol 194:4151-4160

Tamaki H, Hanada S, Sekiguchi Y, Tanaka Y, Kamagata Y (2009) Effect of gelling agent on colony formation in solid cultivation of microbial community in lake sediment. Environ Microbiol 11:1827-1834

Taupp M, Mewis K, Hallam SJ (2011) The art and design of functional metagenomic screens. Curr Opin Biotechnol 22:465-472

Tchigvintsev A, Tran H, Popovic A, Kovacic F, Brown G, Flick R, Hajighasemi M, Egorova O, Somody JC, Tchigvintsev D, Khusnutdinova A, Chernikova TN, Golyshina OV, Yakimov MM, Savchenko A, Golyshin PN, Jaeger KE, Yakunin AF (2014) The environment shapes microbial enzymes: five cold-active and salt-resistant carboxylesterases from marine metagenomes. Appl Microbiol Biotechnol. doi:10.1007/s00253-014-6038-3

Temperton B, Giovannoni SJ (2012) Metagenomics: microbial diversity through a scratched lens. Curr Opin Microbiol 15:605-612

Ten LN, Im WT, Kim MK, Kang MS, Lee ST (2004) Development of a plate technique for screening of polysaccharide-degrading microorganisms by using a mixture of insoluble chromogenic substrates. J Microbiol Methods 56:375-382

Ten LN, Im WT, Kim MK, Lee ST (2005) A plate assay for simultaneous screening of polysaccharide- and protein-degrading micro-organisms. Lett Appl Microbiol 40:92-98
Uchiyama T, Miyazaki K (2010) Product-induced gene expression, a product-responsive reporter assay used to screen metagenomic libraries for enzyme-encoding genes. Appl Environ Microbiol 76:7029-7035

Uchiyama T, Abe T, Ikemura T, Watanabe K (2005) Substrate-induced gene-expression screening of environmental metagenome libraries for isolation of catabolic genes. Nat Biotechnol 23:88-93

van der Maarel MJ, van der Veen B, Uitdehaag JC, Leemhuis H, Dijkhuizen L (2002) Properties and applications of starchconverting enzymes of the alpha-amylase family. J Biotechnol 94:137-155

Vartoukian SR, Palmer RM, Wade WG (2010) Strategies for culture of 'unculturable' bacteria. FEMS Microbiol Lett 309:1-7

Vester JK, Glaring MA, Stougaard P (2013) Improving diversity in cultures of bacteria from an extreme environment. Can J Microbiol 59:581-586

Vester JK, Glaring MA, Stougaard P (2014a) An exceptionally cold-adapted alpha-amylase from a metagenomic library of a cold and alkaline environment. Appl Microbiol Biotechnol. doi:10.1007/s00253-014-5931-0

Vester JK, Glaring MA, Stougaard P (2014b) Discovery of novel enzymes with industrial potential from a cold and alkaline environment by a combination of functional metagenomics and culturing. Microb Cell Fact 13:72

Voget S, Leggewie C, Uesbeck A, Raasch C, Jaeger KE, Streit WR (2003) Prospecting for novel biocatalysts in a soil metagenome. Appl Environ Microbiol 69:6235-6242

Wang K, Li G, Yu SQ, Zhang CT, Liu YH (2010) A novel metagenome-derived beta-galactosidase: gene cloning, overexpression, purification and characterization. Appl Microbiol Biotechnol 88:155-165

Warren RL, Freeman JD, Levesque RC, Smailus DE, Flibotte S, Holt RA (2008) Transcription of foreign DNA in Escherichia coli. Genome Res 18:1798-1805

Wei P, Bai L, Song W, Hao G (2009) Characterization of two soil metagenome-derived lipases with high specificity for $p$-nitrophenyl palmitate. Arch Microbiol 191:233-240

Wierzbicka-Wos A, Cieslinski H, Wanarska M, Kozlowska-Tylingo K, Hildebrandt P, Kur J (2011) A novel cold-active beta-D-galactosidase from the Paracoccus sp. 32d-gene cloning, purification and characterization. Microb Cell Fact 10:108

Wierzbicka-Wos A, Bartasun P, Cieslinski H, Kur J (2013) Cloning and characterization of a novel cold-active glycoside hydrolase family 1 enzyme with beta-glucosidase, beta-fucosidase and beta-galactosidase activities. BMC Biotechnol 13:22

Williamson KE, Kan J, Polson SW, Williamson SJ (2011) Optimizing the indirect extraction of prokaryotic DNA from soils. Soil Biol Biochem 43:736-748

Wu G, Wu G, Zhan T, Shao Z, Liu Z (2013) Characterization of a cold-adapted and salt-tolerant esterase from a psychrotrophic bacterium Psychrobacter pacificensis. Extremophiles 17:809-819

Yilmaz S, Allgaier M, Hugenholtz P (2010) Multiple displacement amplification compromises quantitative analysis of metagenomes. Nat Methods 7:943-944

Yu EY, Kwon MA, Lee M, Oh JY, Choi JE, Lee JY, Song BK, Hahm DH, Song JK (2011) Isolation and characterization of coldactive family VIII esterases from an arctic soil metagenome. Appl Microbiol Biotechnol 90:573-581

Zengler K, Toledo G, Rappe M, Elkins J, Mathur EJ, Short JM, Keller M (2002) Cultivating the uncultured. Proc Natl Acad Sci USA 99:15681-15686 